\title{
KUALITAS BAKTERIOLOGIS (MPN COLIFORM) PADA SUMBER MATA AIR DI DESA BUNTU AMPANG KEC. BAROKO KAB. ENREKANG
}

Bacteriological Quality (Mpn Coliform) In Water Eye Sources In Buntu Ampang Village Kec. Baroko Kab. Enrekang

\author{
1,2 Jurusan Kesehatan Lingkungan Poltekkes Kemenkes Makassar \\ fwahdaniyah@gmail.com
}

\begin{abstract}
Water is the most important substance in life after air, village Buntu Ampang Kec. Baroko Kab. Enrekang is one area that utilizes the spring as a source of clean water for everyday life. The purpose of this study is "to get a general description of the source of water in the village of Buntu Ampang Kec. Baroko Kab. Enrekang ". The type of this research is descriptive observasional research that aims to determine the quality of MPN Coliform in the spring. Number of MPN Coliform at source of springs of $>2400 / 100 \mathrm{ml}$ sample, Distribution 1,79/100 m/ samples, Distribution 1 nearest $>2400 / 100 \mathrm{ml}$ sample, The distribution of 1 is $>2400 / 100 \mathrm{ml}$ sample, Distribution 1 farthest $>2400 / 100 \mathrm{ml}$, Sample while for Distribution 2 got result > 2400/100 ml sample, Distribution 2 closest > 2400/100m/ sample, Medium 2 distribution > 2400/100 ml sample, Farthest distribution > 2400/100 ml samples. Therefore, the results obtained for MPN coliform examination are not eligible. Based on the results of research Coliform MPN and the construction of springs, it is not in accordance with the health requirements and construction requirements for alternative problem solving that can be given is processed first before being consumed directly, Improving the construction of building and maintain Springs.
\end{abstract}

Keyword : Springs \& MPN Coliform

\section{ABSTRAK}

Air merupakan zat yang paling penting dalam kehidupan setelah udara, Desa Buntu Ampang Kec. Baroko Kab. Enrekang merupakan salah satu daerah yang memanfaatkan mata air sebagai sumber air bersih bagi kehidupan sehari-hari. Tujuan dalam penelitian ini yaitu "untuk mendapatkan gambaran umum sumber mata air di Desa Buntu Ampang Kec. Baroko Kab. Enrekang". Jenis penelitian ini adalah penelitian observasional yang bersifat deskriptif yang bertujuan untuk mengetahui kualitas MPN Coliform pada sumber mata air. Jumlah MPN Coliform pada sumber mata air sebanyak > 2400/100 ml sampel, Distribusi 1, 79/100 ml sampel, Distribusi 1 terdekat > 2400/100 ml sampel, Distribusi 1 sedang $>2400 / 100 \mathrm{ml}$ sampel, Distribusi 1 terjauh $>2400 / 100 \mathrm{ml}$ sampel sedangkan untuk Distribusi ke 2 didapatkan hasil $>2400 / 100 \mathrm{ml}$ sampel, Distribusi 2 terdekat $>2400 / 100 \mathrm{ml}$ sampel, Distribusi 2 sedang $>2400 / 100 \mathrm{ml}$ sampel, Distribusi terjauh $>2400 / 100 \mathrm{ml}$ sampel. Olah sebab itu hasil yang didapatkan untuk pemeriksaan MPN coliform tidak memenuhi syarat. Berdasarkan hasil penelitian MPN Coliform serta konstruksi sumber mata air, tidak memenuhi syarat kesehatan serta syarat konstruksi alternatif pemecahan masalah yang dapat diberikan adalah diolah terlebih dahulu sebelum dikonsumsi secara langsung, memperbaiki konstruksi bangunan dan memelihara sumber mata air.

Keyword : Mata Air, MPN Coliform

\section{PENDAHULUAN}

Air merupakan zat yang paling penting dalam kehidupan setelah udara. Permasalahan lingkungan yang dijumpai di negara Indonesia pada saat ini adalah terjadinya banjir pada musim hujan dan kekeringan pada musim kemarau. Selain itu, terjadinya penurunan air permukaan tanah di beberapa tempat. Hal ini disebabkan adanya penurunan kemampuan tanah untuk meresapkan air sebagai akibat adanya perubahan lingkungan yang merupakan dampak dari proses pembangunan. Saat ini, krisis air sudah mulai nyata dirasakan masyarakat Indonesia. (Widi Handoro).

Selain kuantitas air, kualitas air merupakan hal yang perlu mendapatkan perhatian.Berdasarkan Permenkes Nomor 32 Tahun 2017 tentang persyaratan kualitas air bersih bagi masyarakat dan syarat tersebut merupakan satu kesatuan. Maka dari itu air yang digunakan harus memenuhi syarat dari segi kualitas dan kuantitasnya, karena air sangat berpengaruh terhadap kesehatan baik secara langsung maupun tidak langsung. Pertimbangan dari berbagai aspek perlu diperhatikan sebagai dasar perencanaan penyediaan air bersih yang memenuhi syarat, agar air tidak memberikan dampak yang sangat besar terhadap kesehatan bagi manusia diupayakan agar memenuhi syarat kesehatan baik dari segi fisik, kimia, bakteriologis dan radioaktif.

Kejadiaan diare merupakan salah satu permasalahan kesehatan bagi masyarakat di Indonesia baik di desa maupun di perkotaan. Diare dapat diartikan sebagai suatu kondisi dimana seseorang buang air besar yang memiliki tinja berbentuk cair, hal tersebut disebabkan oleh bakteri, virus, parasit serta keracunan (Depertemen Kesehatan RI, 2011). Data Badan Pusat Statistik mengenai jenis penyakit yang diderita di Desa Buntu Ampang Kec. Baroko Kab. Enrekang di dapatkan penyakit diare sebanyak 748 orang pada tahun 2015 (Badan Pusat Statistik 
2016).Desa Buntu Ampang Kec. Baroko Kab. Enrekang merupakan salah satu daerah yang memanfaatkan mata air sebagai sumber air bersih bagi kehidupan sehari - hari, dimana tempat sumber mata air memiliki kondisi fisik yang terbuka, tidak memiliki pengamanan (Pagar). Warga sekitar memanfaatkan sumber mata air ini dengan cara memasang pipa - pipa yang dialirkan menuju rumah penduduk.

\section{METODE}

Lokasi penelitian yaitu sumber mata air di Desa Buntu Ampang, Kec. Baroko Kab. Enrekang. dan pemeriksaan dilakukan di Laboratorium Jurusan Kesehatan Lingkungan Poltekkes Kemenkes Makassar.

Pengumpulan Data

Dalam penelitian ini dikumpulkan data dengan cara yaitu :

a) Data Primer

Data primer yang diperoleh dengan melakukan observasi lapangan serta hasil pemeriksaan kualitas MPN Coliform dan konstruksi bangunan sumber mata air.

b) Data Sekunder

Data skunder diperoleh dari laporan profil tahunan Badan Pusat Statistik 2016 tentang data penyakit, jurnal berbagai referensi instansi dalam penelitian ini, serta beberapa buku yang terkait dengan hasil studi yang ada hubunganya dengan objek penelitian.

\section{Pengolahan dan analisis data}

Hasil pengamatan kondisi konstruksi sumber mata air dan pemeriksaan MPN Coliform dianalisa secara deskriptif untuk mengetahui kualitas MPN Coliform sumber mata air di Desa Buntu Ampang Kec. Baroko Kab. Enrekang.

\section{HASIL}

Tabel 1

MPN Coliform Pada Sumber Mata Air \& Distribusi Ke Masyarakat Di Desa Buntu Ampang Kec. Baroko Kab. Enrekang

\begin{tabular}{llcl}
\hline $\begin{array}{l}\text { N } \\
\text { o. }\end{array}$ & $\begin{array}{l}\text { Lokasi/Distri } \\
\text { busi }\end{array}$ & $\begin{array}{l}\text { Hasil } \\
\text { Pemeriks } \\
\text { aan (/100 } \\
\text { ml } \\
\text { sampel) }\end{array}$ & $\begin{array}{l}\text { Keteran } \\
\text { gan }\end{array}$ \\
\hline & $\begin{array}{l}\text { Sumber Mata } \\
\text { air }\end{array}$ & $>2400$ & TMS \\
\hline $\mathbf{1}$ & Distribusi 1 & 79 & TMS \\
\hline $\mathbf{2}$ & $\begin{array}{l}\text { Distribusi 1 } \\
\text { Terdekat }\end{array}$ & $>2400$ & TMS \\
\hline $\mathbf{3}$ & $\begin{array}{l}\text { Distribusi 1 } \\
\text { Sedang }\end{array}$ & $>2400$ & TMS \\
\hline $\mathbf{4}$ & $\begin{array}{l}\text { Distribusi 1 } \\
\text { Terjauh }\end{array}$ & $>2400$ & TMS \\
\hline $\mathbf{5}$ & $\begin{array}{l}\text { Distribusi 2 } \\
\text { Distribusi 2 }\end{array}$ & $>2400$ & TMS \\
\hline $\mathbf{6}$ & $\begin{array}{l}\text { Terdekat } \\
\text { Teristribusi 2 }\end{array}$ & $\begin{array}{l}\text { Distang } \\
\text { Sedang }\end{array}$ & TMS \\
\hline $\mathbf{8}$ & $\begin{array}{l}\text { Distribusi 2 } \\
\text { Terjauh }\end{array}$ & $>2400$ & TMS \\
\hline
\end{tabular}

Tabel 2

Observasi Konstruksi Sumber Mata Air

\begin{tabular}{|c|c|c|c|}
\hline \multirow{2}{*}{$\begin{array}{l}\mathbf{N} \\
\mathbf{0} .\end{array}$} & \multirow{2}{*}{$\begin{array}{l}\text { Syarat Konstruksi } \\
\text { Sumber Mata Air Desa } \\
\text { Buntu Ampang Kec. } \\
\text { Baroko Kab. Enrekang }\end{array}$} & \multicolumn{2}{|c|}{ Hasil } \\
\hline & & $\mathrm{Ya}$ & $\begin{array}{l}\text { Tid } \\
\text { ak }\end{array}$ \\
\hline 1 & $\begin{array}{l}\text { Sumber mata air } \\
\text { mempunyai penutup }\end{array}$ & $\sqrt{ }$ & \\
\hline 2 & $\begin{array}{l}\text { sumber mata air } \\
\text { mempunyai saluran } \\
\text { pembuangan air limbah }\end{array}$ & & $\sqrt{ }$ \\
\hline 3 & $\begin{array}{l}\text { sumber mata air } \\
\text { mempunyai perlindungan } \\
\text { pagar. }\end{array}$ & & $\sqrt{ }$ \\
\hline 4 & $\begin{array}{l}\text { memiliki bak perlindungan } \\
\text { seperti atap }\end{array}$ & & $\sqrt{ }$ \\
\hline 5 & $\begin{array}{l}\text { Memiliki ukuran garis } \\
\text { tengah minumum } 60 \mathrm{~cm} \\
\text { (sebaiknya bundar) pada } \\
\text { atas bak penampunganya. }\end{array}$ & & $\sqrt{ }$ \\
\hline & Jumlah & 1 & 4 \\
\hline
\end{tabular}


Tabel 3

Observasi Distribusi Sumber Mata Air

\begin{tabular}{|c|c|c|c|}
\hline \multirow[t]{2}{*}{ No. } & \multirow[t]{2}{*}{ Sistem Distribusi } & \multicolumn{2}{|c|}{ Jumlah } \\
\hline & & $\mathrm{Ya}$ & Tidak \\
\hline 1. & $\begin{array}{l}\text { Sistem jaringan pipa } \\
\text { distribusi pada sumber } \\
\text { mata air sampai ke outlet }\end{array}$ & $\sqrt{ }$ & \\
\hline 2. & $\begin{array}{l}\text { Jenis pipa yang } \\
\text { digunakan adalah plastik }\end{array}$ & $\sqrt{ }$ & \\
\hline 3. & $\begin{array}{l}\text { Pipa yang digunakan } \\
\text { dalam keadaan baik }\end{array}$ & $\sqrt{ }$ & \\
\hline 4. & $\begin{array}{l}\text { Jarak sumber mata air } \\
\text { dari distribusi } 1 \text { memiliki } \\
\text { kondisi pipa baik }\end{array}$ & $\sqrt{ }$ & \\
\hline 5. & $\begin{array}{l}\text { Jarak mata air dari } \\
\text { distribusi } 1 \text { ke } 2 \text { memiliki } \\
\text { kondisi pipa yang baik }\end{array}$ & $\sqrt{ }$ & \\
\hline & TOTAL & 5 & 0 \\
\hline
\end{tabular}

\section{PEMBAHASAN}

1) Kualitas MPN Colifrom Sumber Mata Air

Berdasarkan

hasil pemeriksaan mengenai MPN Coliform dari sumber mata air diperoleh hasil yang tidak memenuhi syarat yaitu $>2400 / 100 \mathrm{ml}$ sampel, syarat berdasarkan Permenkes RI Nomor 32 Tahun 2017 tentang persyaratan kualitas air bersih yakni 50/100 ml.

Keberadaan MPN Coliform pada sumber mata air yang tinggi disebabkan oleh adanya kandang hewan yang memiliki jarak \pm 11 meter dari sumber mata air, kondisi tempat kurang terpelihara, dan tidak memiliki bak perlindungan, selain itu ikan dapat memasuki sumber mata air tersebut, sehingga dapat mencemari air.

Lokasi distribusi 1 kandungan MPN Coliform pada jarak terdekat diperoleh hasil yang tidak memenuhi syarat yakni $79 / 100 \mathrm{ml}$, untuk jarak yang sedang dan terjauh diperoleh hasil yang tidak memenuhi syarat yakni > 2400 .

Kualitas bakteriologis pada distribusi 1 tidak memenuhi syarat disebabkan oleh kondisi tempat penampungan air yang terbuka dan tidak memiliki penutup, tempat penampungan yang kurang terpelihara dekat dengan kandang pemeliharaan hewan sehingga air dapat terkontaminasi bakteri Coliform hal tersebut yang menjadikan kontaminasi penyebab adanya MPN Coliform pada sumber penampungan untuk Distribusi 1.

Lokasi distribusi 2 di peroleh hasil yang tidak memenuhi syarat yaitu $>2400 / 100 \mathrm{ml}$ contoh air, sedangkan pemeriksaan untuk jarak yang terdekat sampai jarak terjauh juga didapatkan hasil yang tidak memenuhi syarat yakni $>2400 / 100$ ml. Persyaratan Permenkes RI Nomor 32 Tahun 2017 tentang kualitas air bersih adalah 50/100 $\mathrm{ml}$ contoh air.

$$
\text { Penyebab terjadinya }
$$

pencemaran sehingga air yang dihasilkan oleh Distribusi 2 tidak memenuhi syarat yaitu memiliki keadaan tempat penampungan air yang terbuka, tempat penampungan air yang tidak terpelihara dekat dengan kandang pemeliharaan hewan dan penampungan air jarang dibersihkan sehingga hal tersebut yang menjadikan kontaminasi penyebab adanya bakteri Colifrom pada sumber penampungan untuk Distribusi ke 2.

Penyebab rendahnya hasil MPN Coliform distribusi 1 dan distribusi 2 sedang dikarenakan sebagai berikut, Pertumbuhan jazad renik, terutama bakteri dapat digambarkan seperti pada Gambar 1.

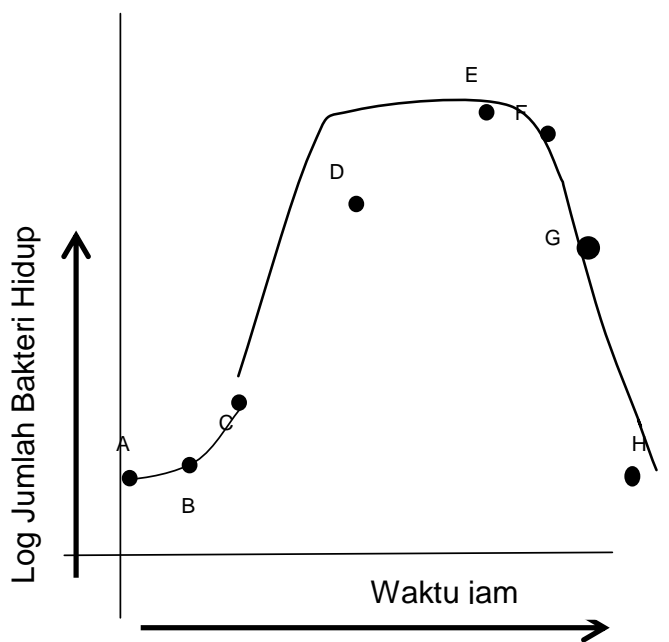

Gambar 41. Grafik pertumbuhan mikroba

A-B : fase permulaan (initial phase)

B-C : fase pertumbuhan dipercepat (phase of accelerated growth)

C-D : fase logaritma (logaritmic phase)

$D-E$ : fase pertumbuhan diperlambat (phase of negative accelerated growth phase) 
$\mathrm{E}-\mathrm{F}$ : fase stationer maksimum (maximum stationery phase)

F-G : fase kematian dipercepat (accelerated death phase)

$\mathrm{G}-\mathrm{H}$ : fase kematian logaritma (logaritmic death phase) Periode awal yang tampaknya tanpa pertumbuhan diikuti oleh suatu periode pertumbuhan yang cepat, kemudian mendatar, dan akhirnya diikuti oleh suatu penurunan populasi sel-sel hidup. Diantara setiap fase ini ada suatu periode peralihan merupakan bagian yang lengkung. Ini menunjukkan lamanya waktu yang berlalu sebelum semua sel memasuki fase yang baru. Hal diatas menunjukkan siklus hidup pertumbuhan bakteriologis.(Supli Effendi, 2009)

Terdapatnya bakteri Coliform dalam air dapat menjadi indikasi besar adanya organisme patogen lainya, Coliform merupakan parameter mikrobiologis terpenting. Meskipun jenis bakteri ini tidak menimbulkan penyakit tertentu secara langsung, keberadaanya didalam air menujukkan tingkat sanitasi rendah, oleh karena itu air harus bebas dari semua jenis Coliform. Bakteri Coliform dapat dibedakan menjadi dua bagian :

a. Coliform fekal, misalanya E.coli, merupakan bakteri yang berasal dari kotaran hewan dan manusia.

b. Coliform non-fekal, misalnya Entrerrobacter aeroginosa, biasanya ditemukan pada hewan atau tanaman mati.(Nugroho 2016)

\section{2) Observasi Konstruksi Sumber Mata} Air

Berdasarkan hasil observasi yang telah dilakukan untuk konstruksi sumber mata air di Desa Buntu Ampang Kec. Baroko Kab. Enrekang dari 5 item yang telah diperiksa. Ada 2 item dari hasil observasi konstruksi yang memenuhi syarat yaitu dimana sumber mata air mempunyai penutup, penutup bak terbuat dari bahan yang kuat dimana keadaan tutup bak terbuat dari bahan semen serta memeiliki bak perlindungan seperti atap, Sedangkan 3 item yang tidak memenuhi syarat adalah sumber mata air tidak mempunyai saluran pembuangan air limbah, sumber mata air tidak memiliki perlindungan pagar, , tidak memiliki ukuran garis tengah minimum $60 \mathrm{~cm}$ (sebaiknya bundar) pada atas bak penampunganya.

Menurut Budi Yuwono $\mathrm{P}$, 2008 bahwa syarat untuk konstruksi sumber mata air sebagai berikut:

a) Syarat konstruksi

b) Tutup bak perlindungan dan dinding bak rapat air, pada bagian atas atau belakang bak perlindungan dibuatkan saluran dan selokan air yang arahnya keluar dari bak, agar tidak mencemari air yang masuk ke bak penangkap.

c) Pada bak perlindungan dilengkapi pipa peluap (Overflow) yang dipasang dengan saringan kawat kasa.

d) Tutup bak (Manhole) terbuat dari bahan yang kuat dan rapat air, ukuran garis tengah minimum $60 \mathrm{~cm}$ (sebaiknya bundar) pada atas bak penampunganya.

e) Pada bak penampung dilengkapi pipa peluap (Overflow) yang dipasang dengan saringan kawat kasa.

f) Lantai bak penampung harus rapat air dan mudah dibersihkan serta mengarah pada pipa penguras.

g) Dilengkapi saluran pembuangan air limbah yang rapat air dan kemiringan minimal 2 \%. (Budi Yuwono $P, 2008)$

\section{3) Observasi Syarat Distribusi Sumber Mata Air}

Berdasarkan hasil observasi yang telah dilakukan untuk syarat distribusi sumber mata air di Desa Buntu Ampang Kec. Baroko Kab. 
Enrekang dari 5 item yang telah di observasi, 5 item yang menjawab Ya. Dimana sistem jaringan pipa distribusi pada sumber mata air sampai ke outlet, jenis pipa yang digunakan adalah plastic, pipa yang digunakan dalam keadaan baik, jarak sumber mata air dari distribusi 1 memiliki kondisi pipa baik, dan jarak mata air dari distribusi 1 ke 2 memiliki kondisi pipa yang baik oleh karena itu untuk obsevasi ditribusi mata air ini telah memenuhi syarat kesehatan.

Adapun syarat distribusi sumber mata air dalah sebagai berikut:

a. Untuk menghindari pengotoran yang harus diperhatikan adalah jarak mata air dengan sumber pengotoran atau pencemaran lainnya.

b. Sumber air harus pada mata air dan diperkirakan mencukupi kebutuhan.

c. Sumber air terdapat pada lokasi air tanah yang terlindung dan tidak mudah longsor yang disebabkan oleh proses alam.

Adapun alternatif pemecahan masalah untuk sumber mata air yang berada di Desa Buntu Ampang Kec. Baroko Kab. Enrekang yakni air bersih tersebut sebaiknya diolah terlebih dahulu sebelum dikonsumsi secara langsung, dengan penambahan desinfektan seperti kaporit dengan memperhitungkan sisa klor maksimal $0,2 \mathrm{mg} / \mathrm{L}$ dan memperbaiki konstruksi dengan memberikan penutup pada penampungan distribusi 1 dan distribusi 2, bangunan pada sumber mata air sehingga menghindari terjadinya pencemaran disekitar serta perlunya adanya penyuluhan dari pemerintah khususnya dari pihak sanitarian di wilayah kerja puskesmas Buntu Ampang. Tingkat pengetahuan masyarakat Desa Buntu Ampang tentang sanitasi masih sangat rendah, dan sebaiknya membentuk sebuah pembinaan POKMAIR (kelompok pemakai air) dimana warga diberi pengetahuan mengenai karakteristik air bersih dan air minum serta karakteristik air yang memiliki kandungan bahan kimia yang berlebihan dalam air, tata laksana pemeriksaan kualitas air secara fisik dan melakukan pengolahan air secara sederhana, cara memasak dan menyimpan air minum yang benar serta diskusi mengenai permasalahan air bersih.

Warga juga dibekali pengetahuan tentang kualitas air bersih dan pengolahn air secara sederhana dengan memanfaatkan bahan - bahan alam yang ada sehingga masyarakat setempat mengetahui kualitas air bila tidak memenuhi standar yang berlaku atau masalah -masalah yang sering ditemui seputar air bersih. Hal ini dilakukan agar masyarakat mampu melakukan pengolahan sederhana pada air yang bermasalah, misalnya bila air tercemar bakteri Coliform sehingga warga menjadi mandiri dan termotivasi untuk memelihara sarana yang telah ada dan dipergunakan.

\section{KESIMPULAN}

a. Hasil Pemeriksaan MPN Coliform pada sumber mata air di Desa Buntu Ampang Kec. Baroko Kab. Enrekang didapatkan hasil yang tidak memenuhi syarat yaitu $>2400 / 100 \mathrm{ml}$ tidak memenuhi syarat sesuai dengan Permenkes RI Nomor 32 Tahun 2017.

b. Hasil observasi yang dilakukan untuk konstruksi ssumber mata air tidak memenuhi syarat dari 5 item yang telah diperiksa hanya 1 item yang memenuhi syarat serta skor yang didapatkan $<60 \%$ dari total pertanyaan tentang konstruksi sumber mata air

c. Hasil observasi yang dilakukan untuk kondisi pada pipa distribusi yang digunakan dari sumber mata air sampai ke masyarakat dalam keadaan yang memenuhi syarat.

\section{SARAN}

a. Membentuk kelompok POKMAIR (kelompok pemakai air) pada masyarakat sebagai wadah penyuluhan, terutama terkait konstruksi.

b. Perlu adanya pemeliharaan tempat lokasi sumber mata air dan tempat penampungan distribusi 1 dan distribusi ke 2 . 


\section{DAFTAR PUSTAKA}

Depkes RI. 2011. Buku Saku Petugas Kesehatan.Jakarta: Direktoral Jendral Pengendalian Penyakit Dan Penyehatan Lingkungan

Depkes RI. 1998. Pedoman Upaya Penyehatan Air Bagi Petugas Sanitasi Puskesmas.

Ervan Ardityan, dkk. 2015. Identifikasi Bakteri Coliform pada Air Kobokan di Rumah Makan Kelurahan Andalas Kecamatan Padang Timur. Hal 845-849, (Online), (http://jurnal.fk.unand.ac.id, Diakses 24 Februari 2017).

Kadek Diana dan Konsukartha. 2007. Pencemaran Air Tanah Akibat Pembuangan Limbah Domestik di Lingkungan Kumuh. Vol. 5 No. 2 Hal 62-108, (Online), Diakses 24 Februari 2017).

Nugroho Tristyanto. 2016. Uji Bakteriologi MPN Coliform dan Eschericia Coli pada Air Baku Kolam Renang di Kota Malang. Malang : PT. Semesta Anugerah.

Republik Indonesia 1990. Permenkes Nomor : 32 Tahun 2017, Tentang Syarat-Syarat dan Pengawasan Kualitas Air.

Rido Wandrivel, dkk. 2012. Kualitas Air Minum yang Diperiksa Depot Air Minum Isi Ulang di Kecamatan Bungus Padang Berdasarkan Persyaratan Mikrobiologi. Hal 129-133, (Online), (http://jurnal.fk.unand.ac.id , Diakses 20 Februari 2017).

Rizka Najla Huwaida, 2014 Faktor - Faktor Yang Mempengaruhi Jumlah Escherichia Coli Air Bersih Pada Penderita Diare Di Kelurahan Pakujaya Kecamatan Serpong Utara Kota Tangerang Selatan, 1-154, (Online), (http: // repository. uinjkt. ac. id/dspace/bitstream/123456789/25645/1/RIZKA\%20NAJLA\%20HUWAIDA\%20-

\%20fkik.pdf, Diakses tanggal 6 Juni 2017) 